\title{
Antibacterial Effects of Extracts of Two Types of Red Sea Algae
}

\author{
Awatif Al-Judaibi \\ Biological Science Department, Microbiology Section, King Abdulaziz University, Jeddah, KSA \\ Email: aamaljudaibi@kau.edu.sa
}

Received 7 March 2014; revised 10 April 2014; accepted 18 April 2014

Copyright (C) 2014 by author and Scientific Research Publishing Inc.

This work is licensed under the Creative Commons Attribution International License (CC BY). http://creativecommons.org/licenses/by/4.0/

\begin{abstract}
Introduction: Intestinal bacteria are exposed many external influences, including drugs, causing the emergence of strains resistant to the effects of antibiotics. Consequently, the discovery of new antibiotics that affect resistant strains is required. Marine algae offer a source of renewable natural compounds with antimicrobial effects. Therefore, the aim of this study was to detect some of these compounds and examine their impact on enteric bacteria. Methodology: Escherichia coli, Salmonella typhi, Shigella dysenteriae, Klebsiella pneumoniae, and Enterobacter aerogenes were tested with extracts of Turbinaria triquetra and Halimeda opuntia extracted with methanol, ethanol, petroleum ether, or dimethyl formamide solvents. We measured bacterial growth inhibition, the minimal inhibitory concentrations (MICs), and potassium leakage, and analyzed the bacterial cells with scanning electron microscopy and energy-dispersive $X$-ray spectroscopy. Results: The $T$. triquetra extract produced with methanol strongly affected the bacteria tested. When the results for T. triquetra and $H$. opuntia were compared with those of omacillin, the T. triquetra and $H$. opuntia extracts in most solvents were more effective than the antibiotic. Differences in the bacterial growth inhibition and MICs depended on the type of alga and the solvent used. At the end of the incubation period, potassium leakage had increased by $62.98 \%$ for $E$. coli, $61.24 \%$ for $S$. typhi, $\mathbf{6 1 . 3 2 \%}$ for $S$. dysenteriae, $\mathbf{6 4 . 0 2 \%}$ for $K$. pneumoniae, and $63.10 \%$ for $E$. aerogenes when treated $T$. triquetra. Conclusion: Turbinaria triquetra extracted with methanol strongly affected the growth of the bacteria tested. Therefore, it is a potential source of natural antibacterial compounds.
\end{abstract}

\section{Keywords}

Turbinaria triquetra, Halimeda opuntia, Antibacterial, Solvents, Enteric Bacteria

\section{Introduction}

Marine macroalgae grow in harsh environments, with variable water currents, a restricted nutrient supply, and 
high concentrations of salt, sunlight, and oxygen, which may foster the production of natural compounds and components that can be used as antimicrobial agents. Algae are also exposed to serious photodynamic damage during their metabolism, which implies that their cells have developed protective mechanisms and compounds [1]-[4]. Macroalgae in the Red Sea are adapted to living in an environment with specific demands. The temperature is often above $35^{\circ} \mathrm{C}$, and the specific nutrients available define their cellular compositions. Marine organisms are under persistent threat of infection by resident pathogenic microbes, including bacteria, and in response, they have evolved complex organic compounds with antibacterial activity, synthesizing them from a diverse set of biological precursors. Macroalgae express highly bioactive compounds that may be exploitable as antimicrobial agents to support both human and animal health. The isolation and identification of new compounds with potential health or pharmaceutical and medicinal activities have attracted intensive research efforts [4] [5].

Several studies have shown the antibacterial effects of macroalgal and plant extracts, including those from the algae Padina tetrostomatica, Syringodium isoetifolium, Haligra sp., Gelidiella acerosa, Laminaria digitata, L. saccharina, Himanthalia elongata, Palmaria palmata, Chondrus crispus, and Enteromorpha spirulina, and plants Dortenia picta and Bridelia micrantha, against several pathogenic bacteria, including Proteus vulgaris, Staphylococcus aureus, Listeria monocytogenes, S. abony, Enterococcus faecalis, Pseudomonas aeruginosa, Klebsiella pneumoniae, K. oxytoca, Ent. cloacae, Serratia marcescens, and Acinetobacter baumannii [3] [6]-[8].

According to studies that have evaluated the effects of cephalothin, fluoroquinolones, and trimethoprim on $E$. coli, the use of antibiotics as antimicrobial treatments is not always optimal. The results indicated that trimethoprim should not be used as antibiotic, and that the resistance of Staphylococcus aureus to ampicillin and penicillin has decreased [9]-[10]. From January 2002 to December 2004, Vibrio cholerae, Shigella spp., and Salmonella spp. were shown to be resistant to ciprofloxacin [11].

In this study, we investigated the potential antimicrobial activity of different bioactive compounds in macroalgae against the pathogenic bacteria E. coli, S. typhi, S. dysenteriae, K. pneumoniae, and Enterobacter aerogenes. The effects of these macroalgal extracts were compared with those of the antibiotic omacillin, a 4-hydroxyl analogue of ampicillin that is a member of the semisynthetic penicillin group and has a wide spectrum of action. This antibiotic displays active bactericidal activity against aerobic Gram-positive bacteria, including Staphylococcus spp. (except strains producing penicillinase) and Streptococcus spp., and aerobic Gram-negative bacteria, including Neisseria gonorrhoeae, N. meningitidis, E. coli, Shigella spp., Salmonella spp., and Klebsiella spp. [12].

\section{Materials and Methods}

\subsection{Study Bacteria}

The bacteria E. coli ATCC 8239, S. typhi ATCC 13289, S. dysenteriae ATCC 2022, K. pneumoniae ATCC 13883, and E. aerogenes ATCC 29751 were tested with the macroalgal extracts. Inocula were prepared by seeding Mueller-Hinton agar (Oxoid CM 337) with $100 \mu \mathrm{l}$ of each bacterium, containing $1 \times 10^{5}$ colony-forming units (cfu).

\subsection{Study Algae and Preparation of Extracts}

The macroalgae were collected from the Red Sea coast between $42^{\circ} \mathrm{W}$ and $20^{\circ} \mathrm{S}$, and were identified by Prof. Hanan Hafez Omer. The algae were washed with seawater and transferred to the laboratory, where they were washed several times with distilled water. They were then spread on plates and dried at $40^{\circ} \mathrm{C}$. The dried algae were ground and solubilized with the solvents methanol, ethanol, petroleum ether, and dimethyl formamide at concentrations of $10 \mathrm{~g} / 100 \mathrm{ml}$. The mixtures were incubated at $30^{\circ} \mathrm{C}$ for $24 \mathrm{~h}$ with shaking at $120 \mathrm{rpm}$, filtered through Whatman No. 1 filter paper, and dried under reduced pressure at $40^{\circ} \mathrm{C}$. The thick deposits produced were dissolved in dimethylsulfoxide (DMSO) at concentrations of $1 \mathrm{~g} / \mathrm{ml}$. The algae identified were Turbinaria triquetra (Phaeophyta) and Halimeda opuntia (Chlorophyta).

\subsection{Antimicrobial Assays}

The antimicrobial activity of each crude macroalgal extract was determined in vitro against the five Gram-negative bacteria. Their activities were measured with disc diffusion and broth dilution methods, as described by the Clinical and Laboratory Standards Institute (CLSI; formerly the National Committee for Clinical Laboratory Standards) [13]. 
Each thick extract deposit was dissolved in DMSO at a concentration of $2 \mu \mathrm{g} / \mathrm{ml}$, and filtered through a 0.22 $\mu \mathrm{m}$-pore filter (Millipore, Billeria, MA). The antibacterial activities of each extract were then investigated by disc diffusion, using filter-paper discs ( $1 \mathrm{~mm}$ diameter, impregnated with $100 \mu \mathrm{l}$ of extract), which were placed on a preinoculated agar surface. Negative controls were prepared using the solvents, and omacillin $(1 \mathrm{mg} / \mathrm{ml})$ was used as the positive control. The plates were incubated at $37^{\circ} \mathrm{C}$ for $24 \mathrm{~h}$, and then the zone of inhibition for each disc was measured. All tests were performed in triplicate and the antimicrobial activities were expressed as the mean inhibition diameter $(\mathrm{mm})$ produced by the macroalgal extract.

\subsection{Minimum Inhibitory Concentrations (MICs)}

The MICs of the extracts that inhibited the growth of the tested bacteria were determined with an agar-dilution method. The bacteria were cultured overnight on Mueller-Hinton agar and then suspended in $1 \mathrm{ml}$ of Mueller-Hinton broth (Oxoid CM 405) at $100 \mathrm{cfu} / \mathrm{ml}$. The agar-dilution analysis was according the NCCLS [14]-[16]. Each extract was serially diluted with Mueller-Hinton broth to final concentrations between 0.25 and $128 \mu \mathrm{l} / \mathrm{ml}$, and then applied to plates inoculated with the test bacteria and incubated at $37^{\circ} \mathrm{C}$ for $24 \mathrm{~h}$. After incubation, the plates were evaluated for the presence or absence of microbial growth. The MIC was determined as the lowest concentration of an extract that allowed no visible bacterial growth [17].

\subsection{Determination of Potassium Leakage}

Overnight nutrient broth cultures of E. coli ATCC 8239, S. typhi ATCC 13289, S. dysenteriae ATCC 2022, K. pneumoniae ATCC 13883, and E. aerogenes were centrifuged and the cells washed three times in deionized water. The cells were resuspended in $5 \mathrm{ml}$ of sterilized deionized water and treated with $50 \mu \mathrm{l}$ of T. triquetra or H. opuntia extracted with methanol. They were then incubated at $37^{\circ} \mathrm{C}$ for $30,60,90,120$, or $180 \mathrm{~min}$, and the levels of $\mathrm{K}^{+}$ions were determined with a potassium-ion-selective electrode [17] [18].

\subsection{Scanning Electron Microscopy (SEM) and Energy-Dispersive X-Ray Spectroscopy (EDAX) Analyses}

For SEM and EDAX observations, a thin film of cells treated with methanol extracts (50 $\mu$ l) of T. triquetra or $H$. opuntia was smeared on a silver stub. The samples were coated with gold by cathodic spraying (Polaron gold), and then dried under a mercury lamp for $5 \mathrm{~min}$. The morphologies of the E. coli, S. dysenteriae, and K. pneumoniae cells were observed with a scanning electronic microscope (Quanta FEG 450) [19]-[21].

\subsection{Statistical Analysis}

The results were analyzed by one-way ANOVA using the SPSS 21 statistical software to compare the mean values of each treatment. The results are expressed as means \pm SE. Probability levels of less than 0.01 were considered highly significant.

\section{Results}

\subsection{Antimicrobial Assays}

The results in Table 1 show the antibacterial effects of T. triquetra and H. opuntia in different solvents on $E$. coli, S. typhi, S. dysenteriae, K. pneumoniae, and E. aerogenes. Methanol extracts showed the greatest inhibition of the test bacteria, with inhibitions of $19 \mathrm{~mm}, 14 \mathrm{~mm}, 14, \mathrm{~mm}, 18 \mathrm{~mm}$, and $17 \mathrm{~mm}$, respectively, for $T$. triquetra; whereas the ethanol and dimethyl formamide extracts had the greatest effects on K. pneumoniae with 16 $\mathrm{mm}$ and $17 \mathrm{~mm}$ inhibition, respectively, for T. triquetra and $19 \mathrm{~mm}$ and $15 \mathrm{~mm}$ inhibition, respectively, for $H$. opuntia. The petroleum ether extract of $H$. opuntia had the lowest effect on the test bacteria, except $K$. pneumoniae (with $13 \mathrm{~mm}$ inhibition), whereas the petroleum ether extract of T. triquetra did not inhibit S. typhi at all.

The results for T. triquetra and $H$. opuntia were compared with those for omacillin. The effects of T. triquetra and $H$. opuntia in most solvents were greater than those of the antibiotic, which has an inhibition of growth (13 $\mathrm{mm}, 11 \mathrm{~mm}, 11 \mathrm{~mm}, 14 \mathrm{~mm}$, and $12 \mathrm{~mm}$, respectively) compared with the increase inhibition of methanol extracts $(19 \mathrm{~mm}, 14 \mathrm{~mm}, 14 \mathrm{~mm}, 18 \mathrm{~mm}, 17 \mathrm{~mm}$, respectively for $T$. triquetra txtract, and $14 \mathrm{~mm}, 12 \mathrm{~mm}, 13 \mathrm{~mm}$, $16 \mathrm{~mm}, 15 \mathrm{~mm}$, respectively for $H$. opuntia extract). 
Table 1. Inhibition of bacterial growth (mm) $24 \mathrm{~h}$ after treatment with $100 \mu \mathrm{l}$. triquetra or H. opuntia extract in different solvents.

\begin{tabular}{|c|c|c|c|c|c|c|c|c|}
\hline \multicolumn{9}{|c|}{$($ mean $\pm \mathrm{SD})$} \\
\hline \multicolumn{9}{|c|}{ solvents } \\
\hline & \multicolumn{2}{|c|}{ Methanol } & \multicolumn{2}{|c|}{ Ethanol } & \multicolumn{2}{|c|}{ Petroleum ether } & Dimethyl formamide & \multirow{2}{*}{ Omacillin } \\
\hline & T. triquetra & H. opuntia & T. triquetra & H. opuntia & T. triquetra & H. opuntia & T. triquetra $\quad$ H. opuntia & \\
\hline E. coli & $19 \pm 0.050^{* *}$ & $14 \pm 0.050^{* *}$ & $11 \pm 0.050^{* *}$ & $13 \pm 0.050^{* *}$ & $12 \pm 0.029^{* *}$ & 0.00 & $13 \pm 0.076^{* *} 12 \pm 0.076^{* *}$ & $13 \pm 0.076^{* *}$ \\
\hline S. typhi & $14 \pm 0.076^{* *}$ & $12 \pm 0.076^{* *}$ & $11 \pm 0.060^{* *}$ & $11 \pm 0.060^{* *}$ & 0.00 & 0.00 & $13 \pm 0.087^{* *} 11 \pm 0.050^{* *}$ & $11 \pm 0.076^{* *}$ \\
\hline S. dysenteriae & $14 \pm 0.076^{* *}$ & $13 \pm 0.109^{* *}$ & $11 \pm 0.050^{* *}$ & $11 \pm 0.060^{* *}$ & $11 \pm 0.029^{* *}$ & 0.00 & $14 \pm 0.029^{* *} 11 \pm 0.076^{* *}$ & $11 \pm 0.076^{* *}$ \\
\hline K. pneumoniae & $18 \pm 0.1202^{* *}$ & $16 \pm 0.0289^{* *}$ & $16 \pm 0.0577^{* *}$ & $19 \pm 0.0882^{* *}$ & $14 \pm 0.0577^{* *}$ & $13 \pm 0.0289^{* *}$ & $17 \pm 0.0577^{* *} 15 \pm 0.077^{* *}$ & $14 \pm 0.076^{* *}$ \\
\hline E. aerogenes & $17 \pm 0.076^{* *}$ & $15 \pm 0.076^{* *}$ & $11 \pm 0.060^{* *}$ & $12 \pm 0.050^{* *}$ & $13 \pm 0.087^{* *}$ & 0.00 & $15 \pm 0.076^{* *} 12 \pm 0.050^{* *}$ & $12 \pm 0.076^{* *}$ \\
\hline
\end{tabular}

\subsection{MICs}

The MICs are shown in Table 2. The extracts of T. triquetra and H. opuntia displayed MICs of $1 \mu \mathrm{l} / \mathrm{ml}$ for $E$. coli in methanol solvent, $2 \mu \mathrm{l} / \mathrm{ml}$ in ethanol with $T$. triquetra, and $8 \mu \mathrm{l} / \mathrm{ml}$ in other solvents, whereas K. pneumoniae and E. aerogenes were less sensitive, with MICs of 8 and $8 \mu \mathrm{l} / \mathrm{ml}$ of $H$. opuntia in methanol, respectively, and the MICs increased to $64 \mu \mathrm{l} / \mathrm{ml}$ of $H$. opuntia in dimethyl formamide for both bacteria. Salmonella typhi and $S$. dysenteriae were more resistant to the antibacterial effects of $T$. triquetra and $H$. opuntia, with MICs of 8,8 , 32 and $16 \mu \mathrm{l} / \mathrm{ml}$ in ethanol, respectively, but these increased to $16,16, \geq 128$ and $128 \mu \mathrm{l} / \mathrm{ml}$ in dimethyl formamide respectively.

\subsection{Potassium Leakage}

The effects of the addition of the T. triquetra and H. opuntia extracts on potassium leakage in $E$. coli, S. typhi, S. dysenteriae, $K$. pneumoniae, and E. aerogenes are shown in Figure 1. Potassium leakage increased with time compared with the control when the bacteria were treated with both algal extracts. After 180 min, potassium leakage increased by $62.98 \%$ or $62.32 \%$ in $E$. coli, $61.24 \%$ or $60.86 \%$ in $S$. typhi, $61.32 \%$ or $61.10 \%$ in $S$. $d y$ senteriae, $64.02 \%$ or $63.28 \%$ in K. pneumoniae, and $63.10 \%$ or $62.84 \%$ in E. aerogenes when treated with $50 \mu 1$ of $T$. triquetra or H. opuntia, respectively.

\subsection{SEM and EDAX Analyses}

The results of an SEM study of the changes in the bacterial morphology and structure in response to the methanol extracts of T. triquetra or H. opuntia are shown in Figure 2 and Figure 3. Treatment with the methanol extracts of $T$. triquetra and $H$. opuntia resulted in cavity in cells, shrinkage, aggregation, rupture, and partial deformation of $E$. coli and $K$. pneumonia, while the effect on $S$. dysenteriae was not high in the cell wall structure. The EDAX analysis of $E$. coli clarified the different elemental compositions of the methanol and ethanol extracts of $T$. triquetra and $H$. opuntia are shown in Figure 4 and Figure 5. Both methanol-based algal extracts contained chlorine, sodium, magnesium, phosphorus, potassium, and sulfur, with additional molybdenum, niobium, zirconium, copper, palladium, and calcium in the T. triquetra extract and a zirconium in the $H$. opuntia extract. The ethanol extracts of both algae contained niobium and phosphorus, whereas the $T$. triquetra extract contained sodium and aluminum and the $H$. opuntia extract contained chlorine, silicon, and potassium.

\section{Discussion}

The environments of seaweeds are harsh because they are exposed to both light and high oxygen concentrations. These factors can lead to the formation of free radicals and other strong oxidizing agents. However, seaweeds rarely experience any serious photodynamic damage during their metabolism. These facts indicate that seaweed cells have evolved protective mechanisms and compounds [22]. Natural products play a valuable role in drug 
Table 2. MIC $(\mu \mathrm{l} / \mathrm{ml})$ of $T$. triquetra and H. opuntia extracts in different solvents for different bacteria $24 \mathrm{~h}$ after treatment.

\begin{tabular}{ccccccccc} 
& \multicolumn{9}{c}{ T. triquetra } \\
& Methanol & Ethanol & Petroleum ether Dimethyl formamide & Methanol & Ethanol & Petroleum ether Dimethyl formamide \\
\hline E. coli & 1.00 & 2.00 & 8.00 & 8.00 & 1.00 & 8.00 & - & 8.00 \\
S. typhi & 2.00 & 8.00 & - & 16.00 & 4.00 & 32.00 & - & $\geq 128$ \\
S. dysenteriae & 2.00 & 8.00 & 32.00 & 16.00 & 4.00 & 16.00 & - & 128 \\
K. pneumoniae & 1.00 & 4.00 & 8.00 & 8.00 & 8.00 & 8.00 & 64.00 & 64.00 \\
E. aerogenes & 1.00 & 8.00 & 16.00 & 8.00 & 8.00 & 16.00 & - & 64.00 \\
\hline
\end{tabular}

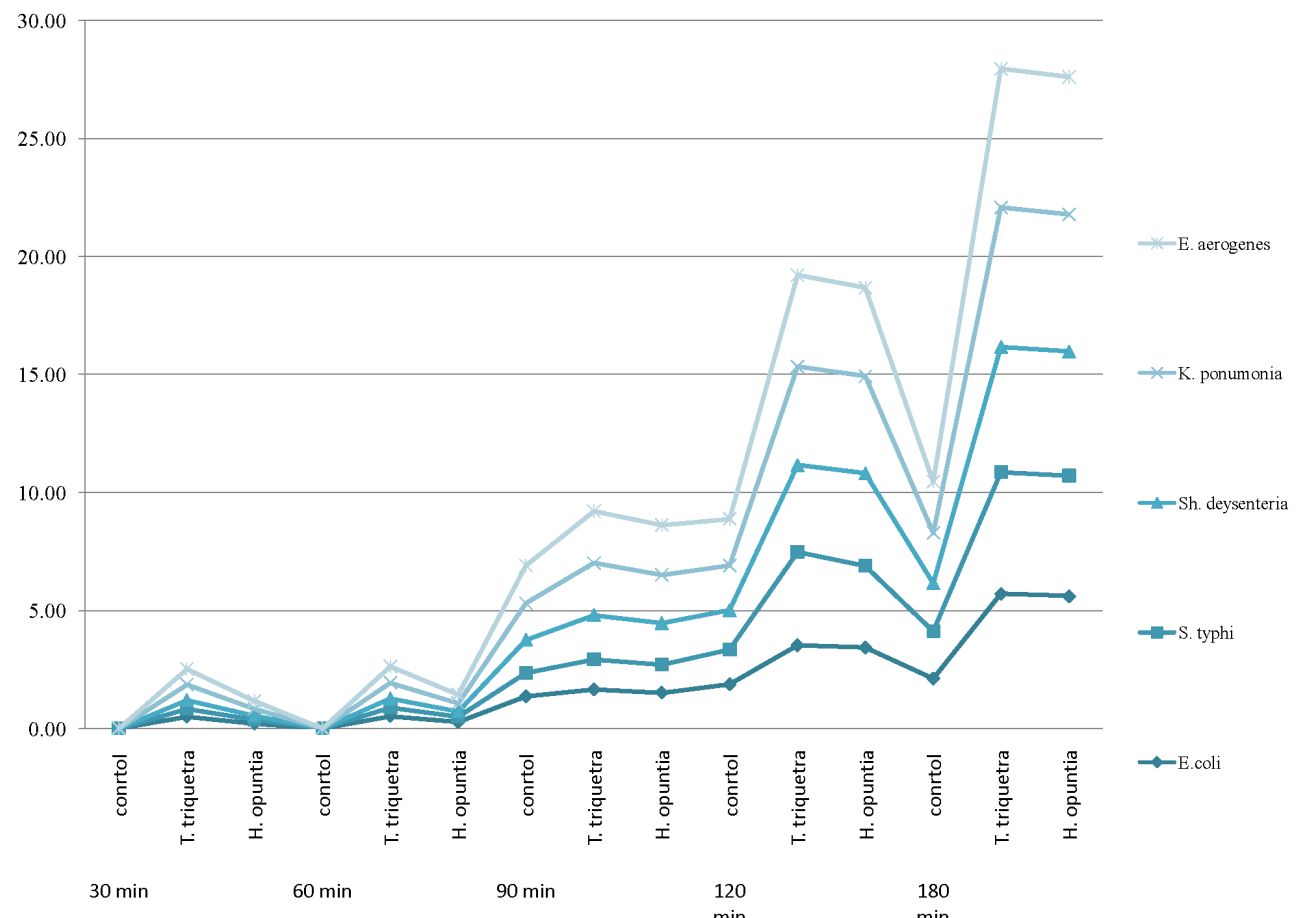

Figure 1. Potassium leakage from bacteria treated with $50 \mathrm{ml}$ of T. triquetra or H. opuntia methanol extract during incubation at $37^{\circ} \mathrm{C}$.

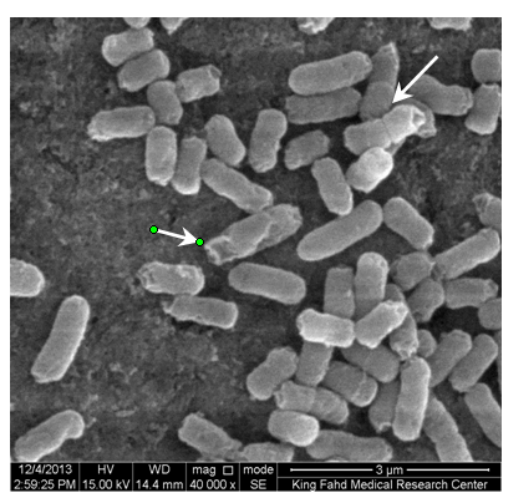

(a)

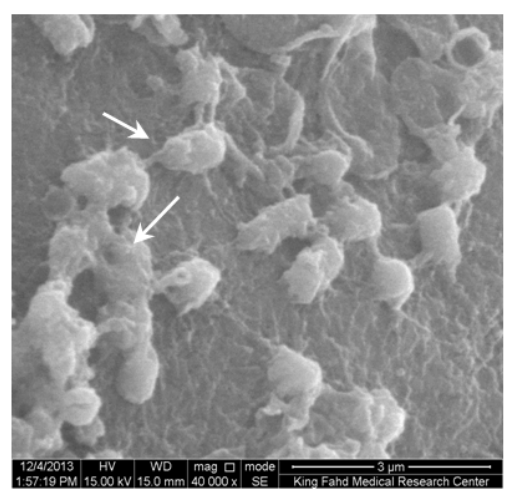

(b)

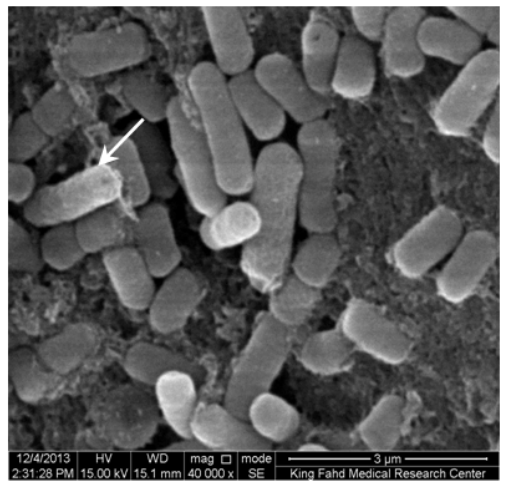

(c)

Figure 2. SEM image of E. coli (a) K. pneumoniae (b) and S. deysenteriae (c) treated with T. triquetra methanol extracts.

discovery. Therefore, the search for novel algal natural compounds should open promising areas of pharmaceutical study. Many reports of biologically active compounds extracted from algae have been published, and con- 


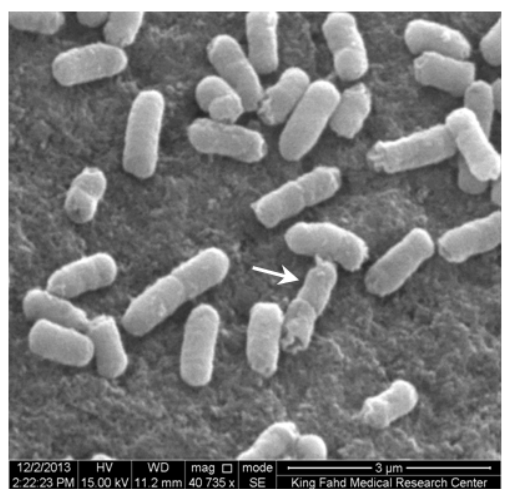

(a)

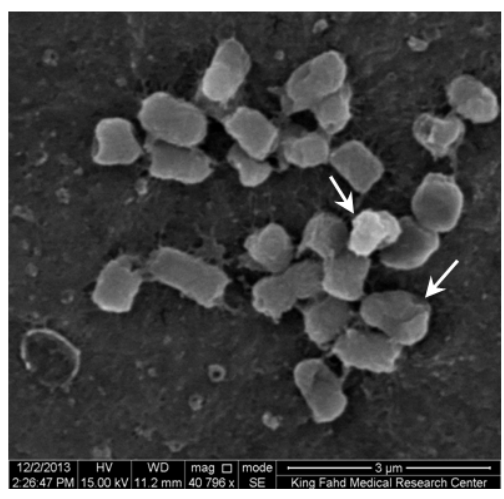

(b)

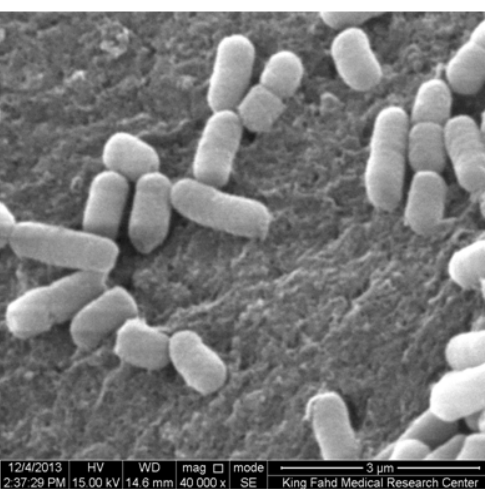

(c)

Figure 3. SEM image of E. coli (a) K. pneumoniae (b) and S. deysenteriae (c) treated with H. opuntia methanol extracts.

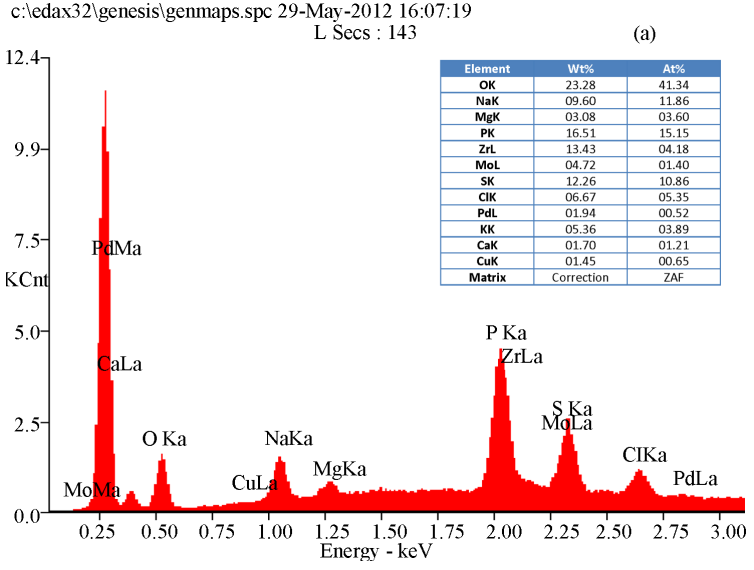

(a)

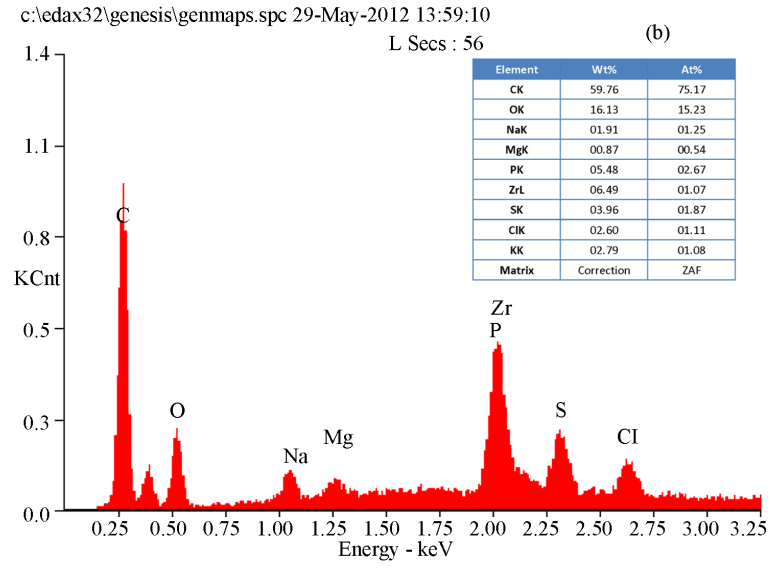

(b)

Figure 4. EDAX analysis of E. coli treated with T. triquetra (a) and H. opuntia (b) extract's with methanol solvent.

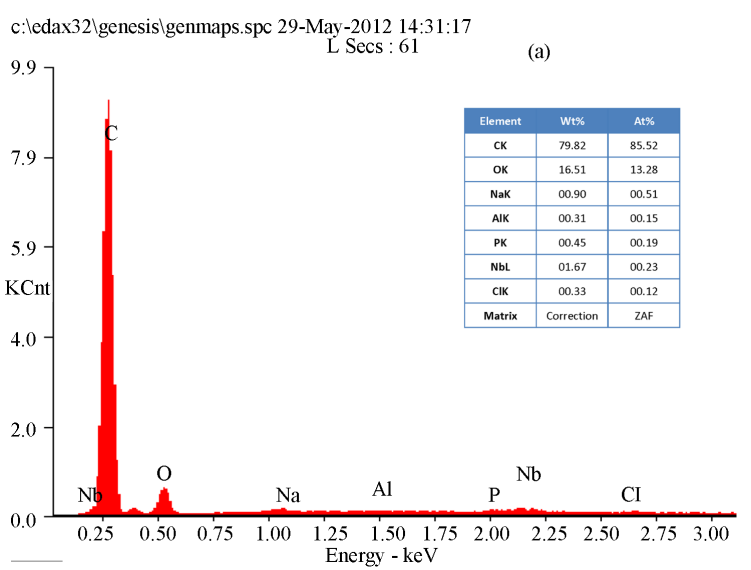

(a)

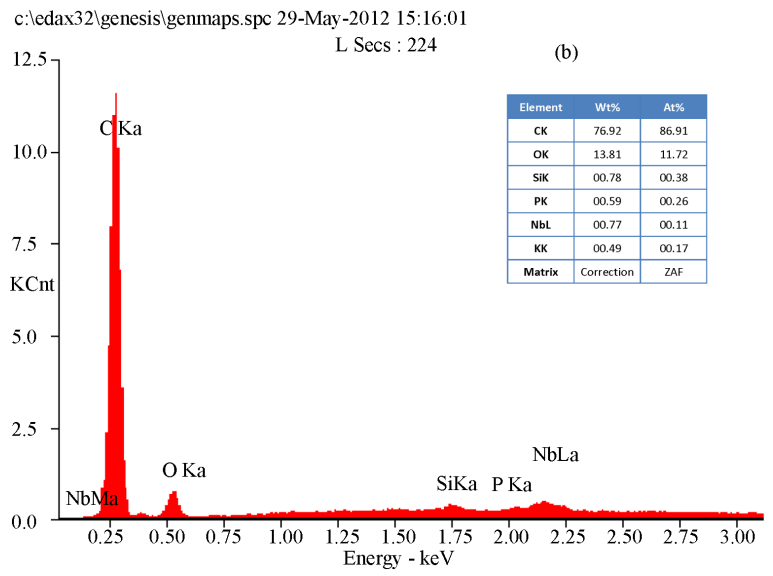

(b)

Figure 5. EDAX analysis of E. coli treated with T. triquetra (a) and H. opuntia (b) extract's with ethanol solvent.

firm their ability to produce metabolites with highly complex and remarkably diverse pharmacological and biological properties [23]-[27].

The bioactive compounds that have been investigated most extensively include those from marine algae and plants. Over 15,000 natural products have been identified. Research into drugs from natural products suggests 
that algae are a promising group in which to discover new biochemically active substances [28].

Many antibiotics are no longer effective in the treatment of mutant bacterial strains. An evolutionary study of antimicrobial resistance to treatment with several antibiotics in strains of E. coli in Dakar [9] suggested that trimethoprim and sulfamethoxazole can no longer be used as empirical treatments for community-acquired urinary tract infection (UTI).

The differences in the antibacterial effects of the algal extracts against E. coli, S. typhi, S. dysenteriae, K. pneumoniae, and E. aerogenes may be attributable to differences in the active compounds that persist in the algae after their extraction with different solvents. In a study of Irish seaweeds, L. digitata, L. saccharina, H. elongata, P. palmata, C. crispus, and Enteromorpha spirulina, found that the potency of the extracts from the different species depended on the solvents used. Methanol was a good solvent for the extraction of brown seaweeds, whereas acetone was better for red and green species [6]. The results of the present study are consistent with the results of a study in which methanol extracts of five lyophilized brown algae at concentrations of 1.0 and $1.5 \mathrm{mg} /$ disk were investigated in vitro for antimicrobial activity, and inhibited the growth of all tested microorganisms, including E. coli ATCC 29998 and S. typhimurium CCM 583 [29]. The antibacterial activities of Calendula officinalis and Cladostephus spongiosus f. verticillatus from the Aegean Sea have also been studied. A methanolic extract of $C$. officinalis showed good activity against E. aerogenes, E. coli, and Enterococcus faecalis [30]. The different antibacterial effects of $T$. triquetra and $H$. opuntia may be attributable to their secondary metabolism and differences in the natural compounds in T. triquetra (Phaeophyta) and H. opuntia (Chlorophyta). Our results are also consistent with those of with Salvador et al. [31], who reported that the family Phaeophyceae had the highest percentage (84\%) of antibacterial activity; Cystoseira was also active against Gram-negative bacteria. In contrast, Kandhasamy et al. [32] observed that E. coli was resistant to methanol extracts of all algae except Sargassum teneerimum. They attributed this difference to the production of bioactive compounds, the season, the method and organic solvents used for extraction, and differences in assay methods. Another study reported that the maximum activity levels were found in the Chlorophyta, and that Flabellia petiolata, Caulerpa prolifera, and Halimeda tuna were the most active species [33].

The observations of the present study indicate that the relationships between the diameters of the inhibition zones and the MIC values varied and may depend on the type of solvent used and the bioactive compounds involved. A possible explanation is that some constituents of the crude extracts influence the diffusion properties of the active compound [6].

Potassium leakage from the E. coli, S. typhi, S. dysenteriae, K. pneumoniae, and E. aerogenes cells after treatment with the methanol extracts can be explained by damage to cellular regulation. This damage can be seen in the electron micrographs and the elements present in the algal extracts, which may attributable to the osmotic stress on the cells or the failure of cell membrane regulation. Other studies have reported the effects of $\mathrm{K}^{+}$on the bacterial outer and cytoplasmic membranes, the regulation of cell transport, and the regulation of the cytoplasmic $\mathrm{pH}$. The major buffer anions are phosphate groups, but cells must use several monovalent cations, and $\mathrm{K}^{+}$is the major cellular cation. One of the parameters that control the movement of $\mathrm{K}^{+}$is the cytoplasmic $\mathrm{pH}$. In $E$. coli, two activities are involved in this control, which vary in the $\mathrm{pH}$ ranges over which they are active, one functioning in alkaline environments and the other in acidic environments [34]. The influx of $\mathrm{K}^{+}$into $E$. coli is essential for the recovery of its turgor, and is required for growth after an osmotic challenge, whereas glutamate levels increase only slightly after osmotic shock. The transporters that mediate $\mathrm{K}^{+}$uptake seem to be controlled by turgor, but the systems involved in $\mathrm{K}^{+}$acquisition in osmotically stressed cells have not yet been identified at the molecular level [35]. A fraction of the total $\mathrm{K}^{+}$concentration is balanced by other small counterions, providing significant osmotic activity. The primary charge separation required for the rapid influx of $\mathrm{K}^{+}$into $E$. coli is provided by endogenously synthesized glutamate [36]. Viejo-Diaz et al. [37] demonstrated that natural antimicrobial peptides, such as kaliocin-1, probably initially attach to the highly anionic lipopolysaccharides on the outer membrane of $E$. coli and gain access to the cytoplasmic membrane by a process called "self-promoted uptake". Another study of the anion balance during the inhibition of E. coli growth by weak acids [38] found that there was no significant difference in the concentrations of free or bound $\mathrm{K}^{+}$in treated cells compared with untreated cells. This suggests that acetate completely replaces the pools of other anions that normally balance the free $\mathrm{K}^{+}$. A reduction in the pools of these anionic metabolites may be why acetate causes growth inhibition at higher pHs. The slow recovery of growth in E. coli cells may be related to these altered pools and possible subsequent changes in enzymatic activities. 


\section{Acknowledgements}

I would like to thank Professor Hanan Hafez Omer for her cooperation and identification of the algae.

\section{References}

[1] Nagshetty, K., Channappa, S.T. and Gaddad, S.M. (2010) Antimicrobial Susceptibility of Salmonella typhi in India. The Journal of Infection in Developing Countries, 4, 070-073.

[2] Poore, A.G.B., Graba-Landry, A., Favret, M., Brennand, H.S., Byrne, M. and Dworjanyn, S.A. (2013) Direct and Indirect Effects of Ocean Acidification and Warming on a Marine Plant-Herbivore Interaction. Oecologia, 173, 1113-1124. http://dx.doi.org/10.1007/s00442-013-2683-y

[3] Chanda, S., Dave, R., Kaneria, M. and Nagani, K. (2010) Seaweeds: A Novel, Untapped Source of Drugs from Sea to Combat Infectious Diseases. In: Mendez-Vilas A., Ed., Current Research, Technology and Education Topics in Applied Microbiology and Microbial Biotechnology, 473-480.

[4] Kumar, S.R., Ramanathan, G., Subhakaran, M. and Inbaneson, S.J. (2009) Antimicrobial Compounds from Marine Halophytes for Silkworm Disease Treatment. International Journal of Medicine and Medical Sciences, 1, 184-191.

[5] Kajiwara, T., Matsui, K., Akakabe, Y., Murakawa, T. and Arai, C. (2007) Antimicrobial Browning-Inhibitory Effect of Flavor Compounds in Seaweeds. Developments in Applied Phycology, 1, 187-196. http://dx.doi.org/10.1007/978-1-4020-5670-3_24

[6] Cox, S., Abu-Ghannam, N., and Gupta, S. (2010) An Assessment of the Antioxidant and Antimicrobial Activity of Six Species of Edible Irish Seaweeds. International Food Research Journal, 17, 205-220.

[7] Gupta, S. and Abu-Ghannam, N. (2011) Bioactive Potential and Possible Health Effects of Edible Brown Seaweeds. Trends in Food Science \& Technology, 22, 315-326. http://dx.doi.org/10.1016/j.tifs.2011.03.011

[8] Salem, W.M., Galal, H., and Nasr El-deen, F. (2011) Screening for Antibacterial Activities in Some Marine Algae from the Red Sea (Hurghada, Egypt). African Journal of Microbiology Research, 5, 2160-2167. http://dx.doi.org/10.5897/AJMR11.390

[9] Sire, J., Nabeth, P., Perrier-Gros-Claude, J., Bahsoun, I., Siby, T., Macondo, E., Gaye-Diallo, A., Guyomard, S., Seck, A., Breurec, S. and Garin, B.T. (2007) Antimicrobial Resistance in Outpatient Escherichia coli Urinary Isolates in Dakar, Senegal. The Journal of Infection in Developing Countries, 1, 263-268.

[10] Gangoué-Piéboji, J., Eze, N., Djintchui, A.N., Ngameni, B., Tsabang, N., Pegnyemb, D.E., Biyiti, L., Ngassam, P., Koulla-Shiro, S. and Galleni, M. (2009) The in-Vitro Antimicrobial Activity of Some Traditionally Used Medicinal Plants against Beta-Lactam-Resistant Bacteria. The Journal of Infection in Developing Countries, 3, 671-680. http://dx.doi.org/10.3855/jidc.77

[11] Kansakar, P., Baral, P., Malla, S. and Ghimire, G.R. (2011) Antimicrobial Susceptibilities of Enteric Bacterial Pathogens Isolated in Kathmandu, Nepal, during 2002-2004. The Journal of Infection in Developing Countries, 5, 163-168. http://dx.doi.org/10.3855/jidc. 1016

[12] Reynolds, J.E.F., Parfitt, K., Parsons, A.V. and Sweetman, S.C. (1996) Martindale the Extra Pharmacopeia. 31st Edition, Royal Pharmaceutical Society, London.

[13] CLSI (2007) Performance Standards for Antimicrobial Susceptibility Testing; Seventeenth Information Supplement. CLSI Document M100-S17 (M2-A7 and M7-A7) 27(1) Clinical and Laboratory Standards Institute, Wayne, Pa.

[14] NCCLS (2006) Performance Standards for Antimicrobial Disk Susceptibility Testing; Approved Standard, Ninth Edition. NCCLS Approved Standard M2-A9 26 (1) Clinical and Laboratory Standards Institute, Wayne, Pa.

[15] NCCLS (2006) Methods for Dilution Antimicrobial Susceptibility Tests for Bacteria That Grow Aerobically; Approved Standard, Seventh Edition. NCCLS Approved Standard M7-A7 26 (2) Clinical and Laboratory Standards Institute, Wayne, $\mathrm{Pa}$.

[16] NCCLS (2002) Performance Standards for Antimicrobial Disk and Dilution Susceptibility Tests for Bacteria Isolated from Animals, Approved Standard. 2nd Edition, NCCLS Document M31-A2 22(6), Clinical and Laboratory Standards Institute, Wayne.

[17] Lambert, R.J.W., Skandamis, P.N., Coote, P.J. and Nychas, G.J.E. (2001) A Study of the Minimum Inhibitory Concentration and Mode of Action of Oregano Essential Oil, Thymol and Carvacrol. Journal of Applied Microbiology, 91, 453-462. http://dx.doi.org/10.1046/j.1365-2672.2001.01428.x

[18] Cox, S.D., Mann, C.M., Markham, J.L., Gustafson, J.E., Warmington, J.R. and Wyllie, S.G. (2001) Determining the Antimicrobial Actions of Tea Tree Oil. Molecules, 6, 87-91.

[19] Ranjan, P., Das, M.P., Kumar, M.S., Anbarasi, P., Sindhu, S., Sagadevan, E. and Arumugam, P. (2013) Green Synthesis and Characterization of Silver Nanoparticles from Nigella sativa and Its Application against UTI Causing Bacteria. 
Journal of Academia and Industrial Research (JAIR), 2, 45-49.

[20] Tyagi, A.K., Bukvicki, D., Gottardi, D., Veljic, M., Guerzoni, M.E., Malik, A., and Marin, P.D. (2013) Antimicrobial Potential and Chemical Characterization of Serbian Liverwort (Porella arboris-vitae): SEM and TEM Observations. Evidence-Based Complementary and Alternative Medicine, 2013, Article ID 382927. http://dx.doi.org/10.1155/2013/382927

[21] Coelho-Souza, S.A., Miranda, M.R., Salgado, L.T., Coutinho, R. and Guimaraes, J.R.D. (2012) Adaptation of the ${ }^{3}$ HLeucine Incorporation Technique to Measure Heterotrophic Activity Associated with Biofilm on the Blades of the Seaweed Sargassum spp. Microbial Ecology, 65, 424-436. http://dx.doi.org/10.1007/s00248-012-0116-9

[22] Matsukawa, R., Dubinsky, Z., Kishimoto, E., Masaki, K., Masuda, Y., Takeuchi, T., Chihara, M., Yamamoto, Y., Niki, E. and Karube, I. (1997) A Comparison of Screening Methods for Antioxidant Activity in Seaweeds. Journal of Applied Phycology, 9, 29-35. http://dx.doi.org/10.1023/A:1007935218120

[23] Cardozo, K.H.M., Guaratini, T., Barros, M.P., Falcão, V.R., Tonon, A.P., Lopes, N.P., Campos, S., Torres, M.A., Souza, A.O., Colepicolo, P. and Pinto, E. (2007) Metabolites from Algae with Economical Impact. Comparative Biochemistry and Physiology Part C: Toxicology \& Pharmacology, 146, 60-78.

[24] Jeyaseelan, E.C., Kothai, S., Kavitha, R., Tharmila, S. and Thavaranjit, A.C. (2012) Antibacterial Activity of Some Selected Algae Present in the Costal Lines of Jaffna Peninsula. International Journal of Pharmaceutical \& Biological Archives, 3, 352-356.

[25] Mearns-Spragg, A., Bregu, M., Boyd, K.G., and Burgess, J.G. (1998) Cross-Species Induction and Enhancement of Antimicrobial Activity Produced by Epibiotic Bacteria from Marine Algae and Invertebrates, after Exposure to Terrestrial Bacteria. Letters in Applied Microbiology, 27, 142-146. http://dx.doi.org/10.1046/j.1472-765X.1998.00416.X

[26] Jeyaseelan, E.C., Kothai, S., Kavitha, R., Tharmila, S. and Thavaranjit, A.C. (2012) Antibacterial Activity of Some Selected Algae Present in the Costal Lines of Jaffna Peninsula. International Journal of Pharmaceutical \& Biological Archives, 3, 352-356.

[27] Mearns-Spragg, A., Bregu, M., Boyd, K.G., and Burgess, J.G. (1998) Cross-Species Induction and Enhancement of Antimicrobial Activity Produced by Epibiotic Bacteria from Marine Algae and Invertebrates, after Exposure to Terrestrial Bacteria. Letters in Applied Microbiology, 27, 142-146. http://dx.doi.org/10.1046/j.1472-765X.1998.00416.x

[28] Blunt, J.W., Copp, B.R., Munro, M.H.G., Northcote, P.T. and Prinsep, M.R. (2005) Marine Natural Products. Natural Product Reports, 22, 15-61. http://dx.doi.org/10.1039/b415080p

[29] Demirel, Z., Yilmaz-Koz, F.F., Karabay-Yavasoglu, U.N., Ozdemir, G. and Sukatar, A. (2009) Antimicrobial and Antioxidant Activity of Brown Algae from the Aegean Sea. Journal of the Serbian Chemical Society, 74, 619-628. http://dx.doi.org/10.2298/JSC0906619D

[30] Taskin, E., Ozturk, M., Taskin, E. and Kurt, O. (2007) Antibacterial Activities of Some Marine Algae from the Aegean Sea (Turkey). African Journal of Biotechnology, 6, 2746-2751.

[31] Salvador, N., Garreta, A.G., Lavelli, L. and Ribera, M. (2007) Antimicrobial Activity of Iberian Macroalgae. Scientia Marina, 71, 101-113.

[32] Kandhasamy, M. and Arunachalam, K.D. (2008) Evaluation of in Vitro Antibacterial Property of Seaweeds of Southeast Coast of India. African Journal of Biotechnology, 7, 1958-1961.

[33] Ballesteros, E., Martin, D. and Uriz, M.J. (1992) Biological Activity of Extracts from Some Mediterranean Macrophytes. Botanica Marina, 35, 481-485.

[34] Epstein, W. (2003) The Roles and Regulation of Potassium in Bacteria. Progress in Nucleic Acid Research and Molecular Biology, 75, 293-320. http://dx.doi.org/10.1016/S0079-6603(03)75008-9

[35] Kempf, B. and Bremer, E. (1998) Uptake and Synthesis of Compatible Solutes as Microbial Stress Responses to HighOsmolality Environments. Archives of Microbiology, 170, 319-330. http://dx.doi.org/10.1007/s002030050649

[36] McLaggan, D., Naprstek, J., Buurman, E.T. and Epstein, W. (1994) Interdependence of K ${ }^{+}$and Glutamate Accumulation during Osmotic Adaptation of Escherichia coli. Journal of Biological Chemistry, 269, 1911-1917.

[37] Viejo-Diaz, M., Andrés, M.T., Pérez-Gil, J., Sánchez, M. and Fierro, J.F. (2003) Potassium Efflux Induced by a New Lactoferrin-Derived Peptide Mimicking the Effect of Native Human Lactoferrin on the Bacterial Cytoplasmic Membrane. Biochemistry (Moscow), 68, 217-227. Translated from Biokhimiya, 68, 260-273.

[38] Roe, A.J., Mclaggan, D., Davidson, I., O’byrne, C. and Booth, I.R. (1998) Perturbation of Anion Balance during Inhibition of Growth of Escherichia coli by Weak Acids. Journal of Bacteriology, 180, 767-772. 